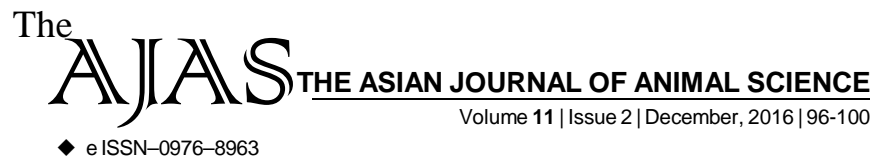

DOI : 10.15740/HAS/TAJAS/11.2/96-100 Visit us | WWW researchjournalco in

- e ISSN-0976-8963

RESEARCH ARTICLE........

\title{
Design aspects of Shark Gill nets of Satpati, Mahatashtra (India)
}

SHREYAS KHATAVKAR, AJAY DESAI AND ASHISH S. MOHITE

Author for Corresponding -

\section{ASHISH S. MOHITE}

Department of Fisheries

Engineering, College of Fisheries,

Shirgaon, RATNAGIRI (M.S.) INDIA

Email: ashishmohite@yahoo.com

See end of the article for

Coopted authors'
ABSTRACT...... Gill net is one of the popular fishing methods along the west coast of India. However, there are regional variation in the design, construction and operation. The present study deals with design, technical specification and operation of Shark gill nets operated off Satpati, Maharashtra. Shark set gill nets were made up of Polyamide (PA) multifilament of diameter $210 \times 4 \times 3$ to $210 \times 6 \times 3 \mathrm{~mm}$. Green and red coloured twine was commonly used for the main webbing in Satpati. The mesh size used for this gill net ranged from 90 to $100 \mathrm{~mm}$ for the main webbing having. The hanging co-efficient ranged between 0.39 to 0.50 and the hung length varied from 25 to $30 \mathrm{~m}$ and the total hung depth varied from 5.07 to $6.15 \mathrm{~m}$. The fleet length of Shark gill net ranged from 2375 to $2875 \mathrm{~m}$. The depth of the operation for Shark gill nets ranged from 60-90 $\mathrm{m}$ and were operated as bottom set gill net.

KEY WORDS...... Gill net, Design, Shark, Shahenshah or Maghari, Scoliodon laticaudus

HOW TO CITE THIS ARTICLE - Khatavkar, Shreyas, Desai, Ajay and Mohite, Ashish S. (2016) Design aspects of Shark Gill nets of Satpati, Mahatashtra (India). Asian J. Animal Sci., 11(2): 96-100. DOI : 10.15740/HAS/TAJAS/11.2/96-100.

ARTICLE CHRONICLE - Received : 08.07.2016; Revised : 08.10.2016; Accepted : 22.10.2016 